\title{
Crisis Transfer Analysis among Fifteen Major World Stock Markets
}

\author{
Suwandi, David Kaluge and Saqib Muneer \\ 'Brawijaya University, Indonesia; wandi1212@gmail.com \\ ${ }^{2}$ Center of Postgraduate Studies, Cenderawasih University, Jayapura, Papua, Indonesia; \\ davidk@ub.ac.id \\ ${ }^{3}$ Department of Business Administration, Government College University Faisalabad, Pakistan; \\ saqibmuneer85@gmail.com
}

\begin{abstract}
Objective: These studies will 1. Examine whether contagion effects exist on composite index of global stocks and 2. Identify and explain the movement of composite stock indexes which have a dominant influence on other countries. 3. Show which markets get the most impact of the turmoil in other countries. Methodology: This study uses daily return composite stock indexes including DJIA, JSX, KLCI, SET, PSEI, BSE, HSI, STI, KOSPI, SCI, NIKKEI 225, FTSE100, DAX 30, CAC40 and IBEX 35 which were taken from January 2007 to October 2015. This study uses a Structural Vector Auto Regression (SVAR) method and focuses on Impulse Response Function (IRF) and Error Variance Decomposition (EVD). Findings: The results of the study show that 1 . Contagion effect exists on composite index of global stocks. 2. The most influential indexes on others are DJIA, KLCI, FTSE, SCI. 3. In contrast, stock markets that have been impacted most are JSX (7), PSEI (6), HIS (6), KOSPI (5), NIKKEI (5). Application: The SVAR analysis found a big picture that markets in Asian Region are more dependent on those in American and Europe. India is the special case. It tends to affect the other Asian markets.
\end{abstract}

Keywords: Asian American European Nexus, Contagion Effect, Empirical Structure, Market Connection, Stock Market Integration, SVAR

\section{Introduction}

Globalization has significantly increased in the last ten years and has an impact on a country's financial stability. Increasing integration in the global economy is largely due to an increase on the efficiency of financial markets which facilitate the flow of capital around the world. The financial market is completely integrated in the event of a situation in which investors get the same risk. This means that the rise and fall of the stock prices of a country will make the rise or fall of stock prices of financial markets in other countries as well. In citing the study done by Ibrahim in 2005shows that the degree of linkages or integration among the stock markets provides important implications for the potential benefits of the international portfolio diversification and financial stability of a country. Highly open economies with extensive international trade are more vulnerable to the external shocks than countries with large proportion of domestic demand.

The real phenomena of the contagion effect after the 1997/1998 Asian crisis was indeed a financial crisis that occurred in the United States triggered by the failure of mortgage payments credit (subprime default) in 2007. Subprime mortgage implicated to the crisis that driving slump international stock markets significantly, as reflected in the fall of stock indexes in developing and developed countries, resulting thedamage to the banking system, weakening currencies of developing countries, commodity prices, and the declining of the debt market. The stock composite index in American Regions, namely DJIA was decreased by $32.19 \%$ in October 2008, respectively. Stock composite index in Asia regions, namely SCI, NIKKEI, KOSPI, HSI, BSE, STI, SET, KLCI, JSX and PSEI also experienced sharp decline as much as $25.23 \%, 51.95 \%, 13.45 \%, 25.8 \%, 23.64,34.7 \%$, $33.52 \%, 14.80,19.60 \%$ and $29.66 \%$, respectively as well.

${ }^{*}$ Author for correspondence 
Stock indexes in the European Area as IBEX 35 Spanish, German DAX, the French CAC40 and the FTSE100 of London stock prices eroded due to the negative impact of the crisis with a sharp drop in the same period amounted to $36.40 \%, 31.11 \%, 42.68 \%$ and $36.79 \%$, respectively. Observingthe crisis that occurs repeatedly, country with highintegrated linkage with other countries would be vulnerable to be affected by the global crisis and very reasonable experienced the contagion effect.

Interestingly, the impact of the crisis could be varied among countriest. In Show that Japanese and EMU markets have been directly affected by the US subprime crisis. However, China's equity market has been mainly unaffected directly. It has been affected indirectly through the Japan. Others studies, have done some researches on contagion effect which come to various results. Based on the above facts, this study will investigate the contagion effect among stock indexes using SVAR model. It focusses on the Contagion through trade channel and financial channels. The aim of the study is to answer whether there is a contagion effect among stock indexes DJIA, JSX, KLCI, SET, PSEI, BSE, HSI, STI, KOSPI, SCI, NIKKEI 225, FTSE100, DAX30, CAC40 and IBEX 35 and which indexes have been responsible more for crises transferring to other economies $\$, 10$.

\section{Methodologies}

\subsection{Research Approach}

The most appropriate model to show the interdependence effects on many markets is the Structural Vector Auto Regression (SVAR) Model. The SVAR is not only capable to show the integration among markets but it indeed has ability to identify how the effect is constructed among the markets. SVAR model has been used by many studies including ${ }^{1-1-1}$. It can be written in state-space form as follows:

The Structural Form is:

$$
A_{0} X_{t}=A_{1}+\sum_{i=1}^{K} A_{1+i} X_{t-i}+\sum_{i=1}^{L} B_{i} Y_{t-i}+\Theta E_{t}
$$

The Reduced Form is:

$$
X_{t}=A_{1}^{*}+\sum_{i=1}^{K} A_{i}^{*} X_{t-i}+\sum_{i=1}^{L} B_{i}^{*} Y_{t-i}+U_{t}
$$

From equation 1 and 2, it can be write the relationship between errors of both as:
Since $U_{t}=A_{0}^{-1} \Theta E_{t}$, implies that:

$\mathrm{A}_{0} \mathrm{U}_{\mathrm{t}}=\Theta \mathrm{E}_{\mathrm{t}}$

Where

$A_{i}^{*}=A_{0}^{-1} A_{i}$

$B_{i}^{*}=A_{0}^{-1} B_{i}$

$X$ is matrix of interdependent variables

$Y$ is matrix of exogenous variables

$\mathrm{U}_{\mathrm{t}}=$ Error of Reduced form

$\mathrm{E}_{\mathrm{t}}=$ Error of Structural form

$\Theta=$ Identity

$\mathrm{X}$ is of the rate of return of stock price. The rate of return is measured as: $x_{t}=\frac{P_{t}-P_{t-1}}{P_{t-1}}$.

The structural parameters (all elements of $A_{0}$ matrix) and residuals (E) can be identified whenever we impose an appropriated restriction in the system equations. This statement can be explained through the variancecovariance matrix of residuals in reduced form model as shown as follows,

Variance of $E$ matrix:

$\sum_{U}=U_{t} U_{t}^{\prime}$ where $U_{t}=A_{0}^{-1} \Theta E_{t}$

$\sum_{U}=\left(A_{0}^{-1} \Theta E_{t}\right)\left(A_{0}^{-1} \Theta E_{t}\right)^{\prime}$

$\sum_{U}=\left(A_{0}^{-1} \Theta E_{t} E_{t} \Theta^{\prime} A_{0}^{-1^{\prime}}\right)$

$\sum_{U}=\left(A_{0}^{-1} \Theta \sum_{E} \Theta^{\prime} A_{0}^{-1^{\prime}}\right)$ where $\sum_{E}=E_{t} E_{t}^{\prime}=\sigma$

Since the covariance matrix $\Sigma_{\mathrm{u}}$ has unique pieces of information as many as $\frac{n^{2}+n}{2}$ which consists of $n$ variances and $\frac{n^{2}-n}{2}$ covariances, we need to put some restriction in matrix of $A_{0}$. The matrix of $A_{0}$ which satisfies the restriction is called as restriction matrix.

\subsection{Identification the Restriction}

The restriction represents the structure relationship among capital markets or among indexes used in this study. Conceptually, the relationship should be starting by theoretical argumentation. Theory should provide identification of what variable should act as explanatory and which one be the dependent. Unfortunately there is no theoretical clue to emphasize the relationship. The alternative way to identify the relationship in the absence of theoretical argumentation is empirical fact relationship ${ }^{\text {f }}$. To identify the factual relationship among 
the indexes, the author applies the approach of EngleGranger Causality test, such as used 17 .

Data used in this study were gathered from internet (Wall Street Journal website). Data collected are of the variables of indexes of sixteen stock markets in the world, namely: DJIA (United States), SCI (China), NIKKEI 225 (Japan), FTSE 100 (United Kingdom), DAX 30 (German), KOSPI (South Korea), HSI (Hong Kong), CAC 40 (France), IBEX 35 (Spain), BSE (India), STI (Singapore), SET (Thailand), KLCI (Malaysia), JSX (Indonesia) and PSEI (Philippines). Data collected are in daily stock price indexes fromonline.wsj.com. The data values are closing daily price from sixteen variable stock markets in time period of January 10, 2007 to October 29, 2015.

Steps to follow in this analysis are as follows: firstly, all stock price indexes are converted into rate of return form. Secondly, to meet the basic requirement in timeseries analysis, all the data were checked their characters of stationarity. This stage is essential to decide whether the model applied should be the stationary model or the non-stationary one. Thirdly is to identify the structural relationship or to build its restriction matrix. This stage applies Engle-Granger causality test. Fourth is to estimate VAR and SVAR. Fifth is to calculate Impulse Response Function and Variance Decomposition, and finally, the last is to capture meanings behind the all calculation.

\section{Results}

\subsection{Stationarity Test}

The stability is identified by using the Augmented DickeyFuller (ADF) test. Table 1 shows the statistical result on the a $(1 \%, 5 \%$ and $10 \%)$. It is proved that data are stationary, and it's appropriate to apply SVAR.

Table 1. Result of Augmented Dickey Fuller (ADF) test

\begin{tabular}{|c|c|c|c|c|}
\hline $\begin{array}{l}\text { Variables } \\
\text { (return) }\end{array}$ & t-statistic & Probability & $\begin{array}{l}\text { De- } \\
\text { gree }\end{array}$ & Result \\
\hline DJIA & -37.86357 & $0.0000^{*}$ & Level & Stationer \\
\hline SCI & -47.07176 & $0.0001^{\star}$ & Level & Stationer \\
\hline NIKKEI 225 & -49.27091 & $0.0001^{\star}$ & Level & Stationer \\
\hline FTSE 100 & -24.42256 & $0.0000^{*}$ & Level & Stationer \\
\hline DAX 30 & -47.79014 & $0.0001^{\star}$ & Level & Stationer \\
\hline KOSPI & -47.33982 & $0.0001^{\star}$ & Level & Stationer \\
\hline HSI & -49.70526 & $0.0001^{\star}$ & Level & Stationer \\
\hline CAC 40 & -50.16613 & $0.0001^{\star}$ & Level & Stationer \\
\hline IBEX 35 & -47.25680 & $0.0001^{\star}$ & Level & Stationer \\
\hline BSE & -45.74921 & $0.0001^{\star}$ & Level & Stationer \\
\hline STI & -47.07324 & $0.0001^{\star}$ & Level & Stationer \\
\hline SET & -46.38249 & $0.0001^{\star}$ & Level & Stationer \\
\hline KLCI & -53.57346 & $0.0001^{\star}$ & Level & Stationer \\
\hline JSX & -43.22255 & $0.0001^{\star}$ & Level & Stationer \\
\hline PSEI & -42.59206 & $0.0001^{\star}$ & Level & Stationer \\
\hline
\end{tabular}

Source : Data processed, Eviews 9, 2016.

\subsection{Identification of Restrictions}

Since no theoretical clue to build the relationship among variables conceptually, the structure of the relation, alternatively, is identified by empirical structure approach. Here, Engle-Grange test is applied and the structure identified in Figure 1.

\begin{tabular}{|c|c|c|c|c|c|c|c|c|c|c|c|c|c|c|c|}
\hline & BS & $\mathrm{CA}$ & D & D. & F & $\mathrm{HI}$ & IBEX & $5 \mathrm{JS}$ & KI & & $\mathrm{NI}$ & & SC & $\mathrm{SE}^{\prime}$ & STI \\
\hline BSE & 1 & $\mathrm{X}$ & $\mathrm{x}$ & $\mathrm{x}$ & $\mathrm{x}$ & & $\mathrm{x}$ & & & & & & & & \\
\hline CAC40 & & 1 & $\mathrm{x}$ & $\mathrm{x}$ & & & & & & & & & & & \\
\hline DAX & & & 1 & $\mathrm{x}$ & & & & & & & & & & & \\
\hline DJIA & & & & 1 & & & & & & & & & & & \\
\hline FTSE & & $\mathrm{x}$ & & $\mathrm{x}$ & 1 & & & & & & & & & & \\
\hline HSI & $\mathrm{x}$ & $\mathrm{x}$ & $\mathrm{x}$ & $\mathrm{x}$ & $\mathrm{x}$ & 1 & $\mathrm{x}$ & $\mathrm{x}$ & & & & & $\mathrm{x}$ & & \\
\hline IBEX_35 & & $\mathrm{x}$ & & $\mathrm{x}$ & & & 1 & & & & & & & & \\
\hline JSX & $\mathrm{x}$ & $\mathrm{x}$ & $\mathrm{x}$ & $\mathrm{x}$ & $\mathrm{x}$ & & $\mathrm{x}$ & 1 & & & & & & & $\mathrm{x}$ \\
\hline KLCI & $\mathrm{x}$ & $\mathrm{x}$ & $\mathrm{x}$ & $\mathrm{x}$ & $\mathrm{x}$ & $\mathrm{X}$ & $\mathrm{x}$ & $\mathrm{x}$ & 1 & $\mathrm{x}$ & & & $\mathrm{x}$ & $\mathrm{X}$ & \\
\hline KOSPI & $\mathrm{x}$ & $\mathrm{x}$ & $\mathrm{x}$ & $\mathrm{x}$ & $\mathrm{x}$ & $\mathrm{x}$ & $\mathrm{x}$ & $\mathrm{x}$ & & 1 & & & & $\mathrm{x}$ & \\
\hline NIKKEI & & $\mathrm{x}$ & $\mathrm{x}$ & $\mathrm{x}$ & $\mathrm{x}$ & $\mathrm{X}$ & $\mathrm{x}$ & $\mathrm{x}$ & $\mathrm{x}$ & $\mathrm{x}$ & 1 & $\mathrm{x}$ & $\mathrm{x}$ & $\mathrm{X}$ & \\
\hline PSEI & $\mathrm{x}$ & $\mathrm{x}$ & $\mathrm{x}$ & $\mathrm{x}$ & $\mathrm{x}$ & $\mathrm{X}$ & $\mathrm{x}$ & $\mathrm{x}$ & $\mathrm{x}$ & $\mathrm{x}$ & & 1 & & $\mathrm{X}$ & \\
\hline SCI & $\mathrm{x}$ & $\mathrm{x}$ & $\mathrm{x}$ & $\mathrm{x}$ & $\mathrm{x}$ & & $\mathrm{x}$ & $\mathrm{x}$ & & & & & 1 & & \\
\hline SET & $\mathrm{x}$ & $\mathrm{x}$ & $\mathrm{x}$ & $\mathrm{x}$ & $\mathrm{x}$ & $\mathrm{X}$ & $\mathrm{x}$ & $\mathrm{x}$ & & & & & & 1 & \\
\hline STI & & & & & & & & & & & & & & & 1 \\
\hline
\end{tabular}

Figure 1. Result of engle-grange test. 


\subsection{Pairwise Granger Causality Tests}

The above matrix is the pattern identified for structural restriction among the 15 capital markets. It should be noticed that symbols in row as the dependent while that in the column is explanatory. Sign $\mathrm{x}$ means there is empirical effect.

\subsection{Selecting the Optimum Lag}

In order to estimate VAR properly, it needs to identify the appropriate number of lag. The time lag identification is presented in following table. Based on the results of the calculations in Table 2, optimum lag used in this study is the lag of one period.

\subsection{Unstructured VAR}

Before fully analyzing VAR, the first step is to estimate the simple VAR. From the simple VAR estimate it is clearly found that there is quite strong relationship among the 15 markets. From Table 3, it is stated that indexes that have most influence on others are DJIA, KLCI, FTSE and SCI. In contrast, stock markets that have been impacted most as reaction towards the turbulence in other market are JSX, PSEI, HIS, KOSPI, and NIKKEI. This result shows that Asian markets are more influenced by outside market especially America and European.

Table 2. VAR lag order selection criteria

\begin{tabular}{lcccccc}
\hline Lag & LogL & LR & FPE & AIC & SC & HQ \\
\hline 0 & 113744.0 & NA & $5.08 \mathrm{e}-64$ & -100.3335 & -100.2930 & -100.3187 \\
1 & 115454.3 & 3395.087 & $1.41 \mathrm{e}-64$ & -101.6165 & $-100.9295^{*}$ & $-101.3659^{*}$ \\
2 & 115915.7 & 909.2076 & $1.18 \mathrm{e}-64$ & -101.7977 & -100.4640 & -101.3111 \\
3 & 116183.0 & 523.2071 & $1.16 \mathrm{e}-64^{*}$ & $-101.8077^{*}$ & -99.82740 & -101.0852 \\
4 & 116352.3 & 328.8224 & $1.26 \mathrm{e}-64$ & -101.7312 & -99.10425 & -100.7727 \\
5 & 116545.3 & 372.2419 & $1.33 \mathrm{e}-64$ & -101.6756 & -98.40206 & -100.4812 \\
6 & 116763.8 & 418.3046 & $1.37 \mathrm{e}-64$ & -101.6425 & -97.72235 & -100.2122 \\
7 & 116963.6 & 379.7164 & $1.44 \mathrm{e}-64$ & -101.5930 & -97.02615 & -99.92675 \\
8 & 117161.5 & $373.1376^{*}$ & $1.52 \mathrm{e}-64$ & -101.5417 & -96.32820 & -99.63950 \\
\hline
\end{tabular}

Source : Data processed, Eviews 9, 2016.

Table 3. Vector autoregression estimates

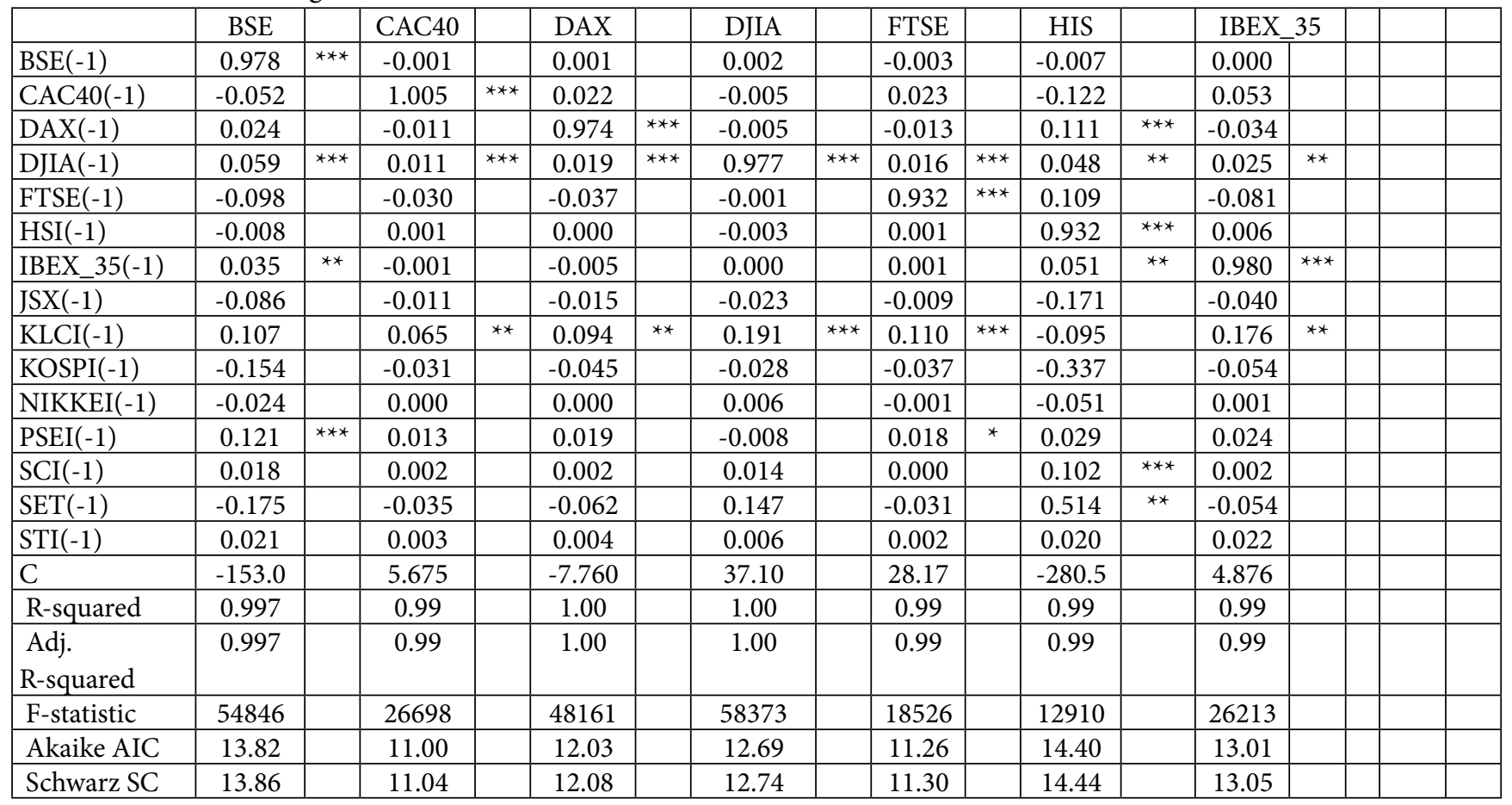




\begin{tabular}{|c|c|c|c|c|c|c|c|c|c|c|c|c|c|c|c|c|}
\hline & JSX & & KLCI & & KOSPI & & NIKKEI & & PSEI & & SCI & & SET & & STI & \\
\hline BSE(-1) & 0.003 & ** & 0.001 & $* *$ & 0.000 & & 0.007 & & 0.002 & * & 0.000 & & 0.000 & & 0.000 & \\
\hline CAC40(-1) & -0.034 & & -0.003 & & -0.002 & & 0.027 & & -0.007 & & -0.005 & & 0.001 & & -0.006 & \\
\hline $\operatorname{DAX}(-1)$ & 0.010 & ** & 0.001 & & 0.006 & $* * *$ & 0.033 & ** & 0.013 & $\star * * *$ & 0.008 & & -0.001 & & -0.001 & \\
\hline DJIA(-1) & 0.005 & ** & 0.001 & & 0.003 & $* *$ & 0.027 & ** & 0.005 & & -0.001 & & 0.003 & $* * *$ & -0.002 & \\
\hline FTSE(-1) & 0.039 & $* * *$ & 0.012 & $* * *$ & 0.013 & $* *$ & 0.117 & $* *$ & 0.034 & $* *$ & 0.014 & & 0.003 & & 0.007 & \\
\hline HSI $(-1)$ & -0.005 & & -0.001 & & -0.003 & & -0.003 & & -0.006 & & -0.005 & & 0.000 & & 0.001 & \\
\hline IBEX_35(-1) & 0.004 & & 0.000 & & 0.001 & & 0.000 & & 0.000 & & 0.006 & & 0.000 & & 0.000 & \\
\hline $\mathrm{JSX}(-1)$ & 0.949 & $* * *$ & -0.003 & & -0.009 & & -0.093 & & 0.012 & & -0.005 & & -0.001 & & 0.016 & ** \\
\hline KLCI(-1) & -0.011 & & 0.968 & $* * *$ & -0.012 & & -0.323 & & -0.047 & & -0.038 & & -0.006 & & 0.008 & \\
\hline KOSPI(-1) & -0.008 & & -0.001 & & 0.958 & $* * *$ & -0.168 & & -0.067 & & 0.006 & & -0.003 & & -0.011 & \\
\hline NIKKEI(-1) & -0.006 & & -0.002 & & -0.004 & & 0.947 & $* * *$ & -0.006 & & -0.003 & & -0.002 & & 0.004 & $* * *$ \\
\hline $\operatorname{PSEI}(-1)$ & 0.006 & & 0.003 & & 0.003 & & 0.064 & $* *$ & 0.969 & $* * *$ & 0.006 & & 0.006 & $* * *$ & -0.008 & \\
\hline SCI(-1) & 0.009 & $* * *$ & 0.001 & & 0.006 & $* * *$ & 0.012 & & 0.008 & $* *$ & 0.998 & $* * *$ & 0.000 & & -0.003 & \\
\hline SET(-1) & 0.055 & ** & -0.004 & & 0.020 & & -0.003 & & 0.071 & $* *$ & 0.012 & & 0.965 & $* * *$ & -0.027 & \\
\hline STI(-1) & -0.001 & & 0.000 & & 0.002 & & 0.010 & & -0.009 & & -0.001 & & -0.001 & & 0.990 & $* * *$ \\
\hline $\mathrm{C}$ & -57.98 & & -8.241 & & -17.98 & & -157.7 & & 7.733 & & -14.38 & & -8.168 & & 24.195 & $* *$ \\
\hline R-squared & 0.999 & & 0.998 & & 0.993 & & 0.997 & & 0.999 & & 0.995 & & 0.999 & & 0.994 & \\
\hline $\begin{array}{l}\text { Adj. } \\
\text { R-squared }\end{array}$ & 0.999 & & 0.998 & & 0.993 & & 0.997 & & 0.999 & & 0.995 & & 0.999 & & 0.994 & \\
\hline F-statistic & 115561 & & 70523 & & 20940 & & 53565 & & 15971 & & 31474 & & 12795 & & 24538 & \\
\hline Akaike AIC & 10.33 & & 7.88 & & 8.93 & & 13.31 & & 10.81 & & 10.98 & & 7.77 & & 9.83 & \\
\hline Schwarz SC & 10.37 & & 7.92 & & 8.97 & & 13.35 & & 10.85 & & 11.02 & & 7.81 & & 9.87 & \\
\hline
\end{tabular}

\subsection{SVAR Estimates}

Analysis on the relationship among error of the reduced form and of the structural ones, which used in SVAR, shows significant relationship as shown in Table 4a and $4 \mathrm{~b}$. It means that at the time zero $\left(\mathrm{t}_{0}\right)$ the markets have a constant relationship. This result explains that if there is turmoil in one market, all related markets will react very shortly. From the estimation, it is proved that markets that have most effect quickly to others are DJIA, CAC40 DAX, FTSE, IBEX35, and BSE. While markets that are most shortly affected are NIKKEI, PSEI, KLCI, KOSPI, SET, SCI, and JSX. From the structural VAR analysis the big picture of the structure that can be seen is that markets in Asian Region are more dependent on those in American and Europe. India is the special case. It tends to affect the other Asian markets.

Table 4. Result of SVAR estimates

Table 4a. Restriction Matrix (A):

\begin{tabular}{|c|l|c|c|c|c|c|c|c|c|c|c|c|c|c|}
\hline 1 & $\mathrm{C}(9)$ & $\mathrm{C}(20)$ & $\mathrm{C}(30)$ & $\mathrm{C}(43)$ & 0 & $\mathrm{C}(57)$ & 0 & 0 & 0 & 0 & 0 & 0 & 0 & 0 \\
\hline 0 & 1 & $\mathrm{C}(21)$ & $\mathrm{C}(31)$ & 0 & 0 & 0 & 0 & 0 & 0 & 0 & 0 & 0 & 0 & 0 \\
\hline 0 & 0 & 1 & $\mathrm{C}(32)$ & 0 & 0 & 0 & 0 & 0 & 0 & 0 & 0 & 0 & 0 & 0 \\
\hline 0 & 0 & 0 & 1 & 0 & 0 & 0 & 0 & 0 & 0 & 0 & 0 & 0 & 0 & 0 \\
\hline 0 & $\mathrm{C}(10)$ & 0 & $\mathrm{C}(33)$ & 1 & 0 & 0 & 0 & 0 & 0 & 0 & 0 & 0 & 0 & 0 \\
\hline $\mathrm{C}(1)$ & $\mathrm{C}(11)$ & $\mathrm{C}(22)$ & $\mathrm{C}(34)$ & $\mathrm{C}(44)$ & 1 & $\mathrm{C}(58)$ & $\mathrm{C}(80)$ & 0 & 0 & 0 & 0 & $\mathrm{C}(93)$ & 0 & 0 \\
\hline 0 & $\mathrm{C}(12)$ & 0 & $\mathrm{C}(35)$ & 0 & 0 & 1 & 0 & 0 & 0 & 0 & 0 & 0 & 0 & 0 \\
\hline $\mathrm{C}(2)$ & $\mathrm{C}(13)$ & $\mathrm{C}(23)$ & $\mathrm{C}(36)$ & $\mathrm{C}(45)$ & 0 & $\mathrm{C}(59)$ & 1 & 0 & 0 & 0 & 0 & 0 & 0 & $\mathrm{C}(101)$ \\
\hline $\mathrm{C}(3)$ & $\mathrm{C}(14)$ & $\mathrm{C}(24)$ & $\mathrm{C}(37)$ & $\mathrm{C}(46)$ & $\mathrm{C}(52)$ & $\mathrm{C}(60)$ & $\mathrm{C}(81)$ & 1 & $\mathrm{C}(89)$ & 0 & 0 & $\mathrm{C}(94)$ & $\mathrm{C}(96)$ & 0 \\
\hline $\mathrm{C}(4)$ & $\mathrm{C}(15)$ & $\mathrm{C}(25)$ & $\mathrm{C}(38)$ & $\mathrm{C}(47)$ & $\mathrm{C}(53)$ & $\mathrm{C}(61)$ & $\mathrm{C}(82)$ & 0 & 1 & 0 & 0 & 0 & $\mathrm{C}(97)$ & 0 \\
\hline $\mathrm{C}(5)$ & $\mathrm{C}(16)$ & $\mathrm{C}(26)$ & $\mathrm{C}(39)$ & $\mathrm{C}(48)$ & $\mathrm{C}(54)$ & $\mathrm{C}(62)$ & $\mathrm{C}(83)$ & $\mathrm{C}(87)$ & $\mathrm{C}(90)$ & 1 & $\mathrm{C}(92)$ & $\mathrm{C}(95)$ & $\mathrm{C}(98)$ & 0 \\
\hline $\mathrm{C}(6)$ & $\mathrm{C}(17)$ & $\mathrm{C}(27)$ & $\mathrm{C}(40)$ & $\mathrm{C}(49)$ & $\mathrm{C}(55)$ & $\mathrm{C}(63)$ & $\mathrm{C}(84)$ & $\mathrm{C}(88)$ & $\mathrm{C}(91)$ & 0 & 1 & 0 & $\mathrm{C}(99)$ & 0 \\
\hline $\mathrm{C}(7)$ & $\mathrm{C}(18)$ & $\mathrm{C}(28)$ & $\mathrm{C}(41)$ & $\mathrm{C}(50)$ & 0 & $\mathrm{C}(64)$ & $\mathrm{C}(85)$ & 0 & 0 & 0 & 0 & 1 & 0 & 0 \\
\hline $\mathrm{C}(8)$ & $\mathrm{C}(19)$ & $\mathrm{C}(29)$ & $\mathrm{C}(42)$ & $\mathrm{C}(51)$ & $\mathrm{C}(56)$ & $\mathrm{C}(65)$ & $\mathrm{C}(86)$ & 0 & 0 & 0 & 0 & 0 & 1 & 0 \\
\hline 0 & 0 & 0 & 0 & 0 & 0 & 0 & 0 & 0 & 0 & 0 & 0 & 0 & $\mathrm{C}(100)$ & 1 \\
\hline
\end{tabular}


Table 4a. Restriction matrix : B

\begin{tabular}{|c|c|c|c|c|c|c|c|c|c|c|c|c|c|c|}
\hline $\mathrm{C}(102)$ & 0 & 0 & 0 & 0 & 0 & 0 & 0 & 0 & 0 & 0 & 0 & 0 & 0 & 0 \\
\hline 0 & $\mathrm{C}(103)$ & 0 & 0 & 0 & 0 & 0 & 0 & 0 & 0 & 0 & 0 & 0 & 0 & 0 \\
\hline 0 & 0 & $C(104)$ & 0 & 0 & 0 & 0 & 0 & 0 & 0 & 0 & 0 & 0 & 0 & 0 \\
\hline 0 & 0 & 0 & $\mathrm{C}(105)$ & 0 & 0 & 0 & 0 & 0 & 0 & 0 & 0 & 0 & 0 & 0 \\
\hline 0 & 0 & 0 & 0 & $C(106)$ & 0 & 0 & 0 & 0 & 0 & 0 & 0 & 0 & 0 & 0 \\
\hline 0 & 0 & 0 & 0 & 0 & $\mathrm{C}(107)$ & 0 & 0 & 0 & 0 & 0 & 0 & 0 & 0 & 0 \\
\hline 0 & 0 & 0 & 0 & 0 & 0 & $\mathrm{C}(108)$ & 0 & 0 & 0 & 0 & 0 & 0 & 0 & 0 \\
\hline 0 & 0 & 0 & 0 & 0 & 0 & 0 & $\mathrm{C}(109)$ & 0 & 0 & 0 & 0 & 0 & 0 & 0 \\
\hline 0 & 0 & 0 & 0 & 0 & 0 & 0 & 0 & $\mathrm{C}(110)$ & 0 & 0 & 0 & 0 & 0 & 0 \\
\hline 0 & 0 & 0 & 0 & 0 & 0 & 0 & 0 & 0 & $\mathrm{C}(111)$ & 0 & 0 & 0 & 0 & 0 \\
\hline 0 & 0 & 0 & 0 & 0 & 0 & 0 & 0 & 0 & 0 & $\mathrm{C}(112)$ & 0 & 0 & 0 & 0 \\
\hline 0 & 0 & 0 & 0 & 0 & 0 & 0 & 0 & 0 & 0 & 0 & $\mathrm{C}(113)$ & 0 & 0 & 0 \\
\hline 0 & 0 & 0 & 0 & 0 & 0 & 0 & 0 & 0 & 0 & 0 & 0 & $\mathrm{C}(114)$ & 0 & 0 \\
\hline 0 & 0 & 0 & 0 & 0 & 0 & 0 & 0 & 0 & 0 & 0 & 0 & 0 & $\mathrm{C}(115)$ & 0 \\
\hline 0 & 0 & 0 & 0 & 0 & 0 & 0 & 0 & 0 & 0 & 0 & 0 & 0 & 0 & $C(116)$ \\
\hline
\end{tabular}

Source : Data processed, Eviews 9, 2016 Notes: ${ }^{* *}$ means significant at $1 \%$ level

\subsection{Variance De-composite Analysis for Indonesian Market}

Regarding to Indonesian Stock market, the Variance Decomposition analysis shows that the behavior of the Indonesian market depends on internal moving or the situation in the past, and on the behavior of other markets (Given in Table 5). Other markets in this finding are BSE (India), HIS (Hongkong), CAC40 (France), DJIA (America), FTSE (UK), and DAX (Germany).

Based on the analysis of the variance decomposition, it is clearly shown that the Indonesian Stock Market represent by JSX, is significantly dictated by 6 major capital markets in the world namely: ${ }^{18} \mathrm{BSE}$ (India), HIS (Hongkong), CAC40 (France), DJIA (America), FTSE
(UK) and DAX (Germany). This means thata disturbance in Indonesian Capital market is closely related to that happens in six other countries namely India, Hongkong, France, American. UK and Germany, beside the situation in previous period of Indonesian market itself. About $70 \%$ of the disturnce is historical tranfered internally, while the rest is distributed according to its contribution. The contribution of disturbance of the capital market in India, Hongkong, France, American, UK and Germany for the first last period are $16,94 \%, 8,07 \%, 1,85 \%, 0,36 \%$, $0,28 \%$, and $0,03 \%$ respectively. It is interesting that the Indonesian stock market is more closely related to quite far distance markets than to closed spatial neighbour markets such as those located in South East Asian region.

Table 5. Variance decomposition of JSX

\begin{tabular}{|c|c|c|c|c|c|c|c|c|c|c|c|c|c|c|c|}
\hline Peri od & BSE & CAC40 & DAX & DJIA & FTSE & HSI & IBEX_35 & JSX & KLCI & KOS PI & NIK KEI & PSEI & SCI & SET & STI \\
\hline 1 & 16.94 & 1.85 & 0.03 & 0.28 & 0.36 & 8.07 & 0.00 & 72.44 & 0.00 & 0.00 & 0.00 & 0.00 & 0.00 & 0.00 & 0.00 \\
\hline 2 & 17.86 & 2.56 & 0.05 & 0.18 & 0.52 & 7.23 & 0.00 & 71.48 & 0.00 & 0.00 & 0.03 & 0.00 & 0.01 & 0.01 & 0.00 \\
\hline 3 & 18.69 & 3.32 & 0.09 & 0.13 & 0.70 & 6.49 & 0.01 & 70.33 & 0.00 & 0.00 & 0.09 & 0.01 & 0.02 & 0.02 & 0.00 \\
\hline 4 & 19.44 & 4.10 & 0.12 & 0.11 & 0.89 & 5.82 & 0.02 & 69.06 & 0.00 & 0.00 & 0.18 & 0.02 & 0.04 & 0.05 & 0.00 \\
\hline 5 & 20.12 & 4.87 & 0.16 & 0.12 & 1.09 & 5.24 & 0.03 & 67.71 & 0.00 & 0.01 & 0.28 & 0.04 & 0.06 & 0.08 & 0.00 \\
\hline 6 & 20.73 & 5.63 & 0.20 & 0.16 & 1.29 & 4.73 & 0.04 & 66.31 & 0.00 & 0.01 & 0.41 & 0.07 & 0.09 & 0.11 & 0.00 \\
\hline 7 & 21.28 & 6.34 & 0.24 & 0.24 & 1.49 & 4.28 & 0.05 & 64.89 & 0.00 & 0.01 & 0.54 & 0.09 & 0.12 & 0.14 & 0.00 \\
\hline 8 & 21.78 & 7.02 & 0.27 & 0.34 & 1.68 & 3.90 & 0.07 & 63.46 & 0.01 & 0.01 & 0.67 & 0.13 & 0.15 & 0.18 & 0.00 \\
\hline 9 & 22.22 & 7.64 & 0.31 & 0.46 & 1.87 & 3.56 & 0.08 & 62.05 & 0.01 & 0.01 & 0.82 & 0.16 & 0.19 & 0.22 & 0.00 \\
\hline 10 & 22.63 & 8.22 & 0.34 & 0.60 & 2.05 & 3.27 & 0.10 & 60.67 & 0.02 & 0.01 & 0.96 & 0.20 & 0.22 & 0.25 & 0.00 \\
\hline
\end{tabular}




\section{Conclusion}

All above analysis eventually come to conclusion that contagion effect significantly exists on composite index of global stocks.Some markets act causes while other receives the effect. The most influential markets towards others are DJIA (United States), KLCI (Malaysia), FTSE (England), SCI (China). In $^{18}$ contrast, stock markets that have been impacted most are JSX (Indonesia), PSEI (Philipines), HIS (Hongkong), KOSPI (South Korea) and NIKKEI (Japan). In SVAR Analysis, it is proved that markets that have most quickly affected on others are DJIA, CAC40, DAX, FTSE, IBEX35 and BSE. While markets that are most shortly affected are NIKKEI, PSEI, KLCI, KOSPI, SET, SCI and JSX. In respect to the disturbance in Indonesian capital market, it is influenced by other markets. The disturbance in Indonesian Capital market is closely related to that happens in six other countries namely India, Hongkong, France, US, UK and Germany, beside the situation in previous period of Indonesian market itselffl. It is interesting that the Indonesian stock market is more closely related to quite far distance markets than to closed spatial neighbour markets such as those located in South East Asian region.

The findings are important for policy makers and investors. Capital market react so quick and the lag 1 period. Investors have to pay much more attention on the market performance in US and Europe.

\section{References}

1. Aebi V, Sabato G, Schmid M. Risk management, corporate governance and bank performance in the financial crisis. Journal of Banking \& Finance. 2012; 36(12):3213-26.

2. Afnouch A, Hammami S. Contagion during the 2008 financial crisis : The case of BRICS group financial markets and five developed markets. Journal of Business Studies Quarterly. 2014; 6(2):159-86.

3. Aktug RE. Empirical dynamics of emerging financial markets during the global mortgage crisis. Borsa Istanbul Review. 2015; 15(1):17-36.

4. Albulescu CT, Goyeau D, Tiwari AK. Contagion and dynamic correlation of the main European stock index futures markets: A time-frequency approach. Procedia Economics and Finance. 2015; 20:19-27.

5. Alexakis PD, Kenourgios D, Dimitriou D. On emerging stock market contagion: The Baltic region. Research in International Business and Finance. 2015; 36:312-21.

6. Dias MHA, Dias J. Macroeconomic policy transmission and international interdependence: A SVAR application to Brazil and US. EconomiA. 2013; 14(2):27-45.

7. Dimitriou D, Simos T. Contagion channels of the USA subprime financial crisis : Evidence from USA, EMU, China and Japan Equity Markets. Journal of Financial Economic Policy. 2013; 5(1):61-71.

8. FTSE Russel. Classification of markets as developed, advanced emerging, secondary emerging or frontier within globalbenchmarks. 2016. Available from: http://www.ftse. com/products/indices/country-classification. Di Akses pada.

9. Gagnon $\mathrm{MH}$, Gimet $\mathrm{C}$. The impacts of standard monetary and budgetary policies on liquidity and financial markets: International evidence from the credit freeze crisis. Journal of Banking \& Finance. 2013; 37(11):4599-614.

10. International Monetary Fund. Coordinated Portofolio Investment Survey (CPIS). Di Akses pada. 2016. p. 1-153.

11. Kasim HS. Evidence of global financial shocks transmission: Changing nature of stock market integration during the 2007/2008 financial crisis. Journal of Economic Cooperation and Development. 2012; 33(4):117-37.

12. Kaluge D, Puspita W. Asymmetric reaction towards financial shocks in ASEAN countries. Procedia-Social and Behavioral Sciences. 2015; 211:519-27.

13. Kohonen A. On detection of volatility spillovers in overlapping stock markets. Journal of Empirical Finance. 2013; 22:140-58

14. Krutpum K. Contagion effect from eurozone through Thailand on stock markets, SVAR framework. Master of Science Program in Finance (International Program) Faculty of Commerce and Accountancy Thammasat University; 2012. p. 1-44.

15. Ruiz J. Response of Spanish stock market to ECB monetary policy during financial crisis. The Spanish Review of Financial Economics. 2015;13(2):41-7.

16. Stoica O, Diaconasu DE, Socoliuc OR. Dilemma: Regional or international interdependencies in Central and Eastern European stock markets. Procedia Economics and Finance. 2015; 20:601-9.

17. Subana M, Sudrajat L. Dasar-Dasar Penelitian Ilmiah. Bandung: CV Pustaka Pelajar; 2005. Available from: http:// wits.worldbank.org/

18. The World Bank. Stock Traded, total value (\% of GDP). 2016. Available from: http://data.worldbank.org/indicator/ CM.MKT.TRAD.GD.ZS. Di Akses pada

19. World Integrated Trade Solution (WITS). Export Partner Share in percentage export to all countries between 2007 and 2015. 2016. Available from: http://wits.worldbank.org. Di Akses pada. 